Bu makaleye atıfta bulunmak için/To cite this article:

YOĞURTCU, B. KIRANLI GÜNGÖR, S. (2021). Bir Yükseköğretim Kurumunda Örgütsel Gücün Etik İklim ve Etik

Liderlik ile İlişkisi. Atatürk Üniversitesi Sosyal Bilimler Enstitüsü Dergisi, 25 (3), 1151-1170.

\title{
Bir Yükseköğretim Kurumunda Örgütsel Gücün Etik İklim ve Etik Liderlik ile İlişkisi $\left.{ }^{*}\right)$
}

\author{
Burcu YOĞURTCU ${ }^{(* *)}$ \\ Semra KIRANLI GÜNGÖR ${ }^{(* * *)}$
}

Öz: Bu araştırma örgütsel gücün etik iklim ve etik liderlik ile ilişkisini tespit etmeye yönelik olarak gerçekleştirilmişstir. Örgütsel Güç Ölçeği, Etik İklim Ölçeği ve Etik Liderlik Ölçeği Erzincan Binali Yıldırım Üniversitesi'nde görev yapan 529 akademisyene uygulanmıștır. Verilerin analizi için SPSS 25 istatistik programı kullanılmıştır. Verilere betimsel istatistikler, güvenirlik testi, korelasyon, çoklu regresyon analizleri yapılmıştır. Araștırmanın sonucuna göre, örgütsel güç ile etik iklim ve etik liderlik arasında olumlu ve anlamlı bir iliş̧kinin olduğu saptanmıştır. Ödül gücü, meşru güç, uzmanlık gücü, karizmatik güç ve bilgi gücü ile etik iklim ve etik liderlik arasinda olumlu ve anlamlı bir ilişskinin olduğu tespit edilmiștir. Ancak zorlayıcı güç ile etik iklim ve etik liderlik arasında herhangi bir ilişki tespit edilmemiştir. Karizmatik güç, bilgi gücü ve uzmanlık gücü etik iklimi ve etik liderliği yordamaktadır. Yöneticilerin akademisyenlerin etik iklim ve etik liderlik algı düzeylerini arttırmaları için karizmatik güç, bilgi gücü ve uzmanlık gücünü etkili bir biçimde kullanmaları önerilmektedir.

Anahtar Kelimeler: Akademisyen, Örgütsel Güç, Etik İklim, Etik Liderlik

\section{Relation of Organizational Power to Ethical Climate and Ethical Leadership in a Higher Education Institution}

Abstract: The aim is to determine the relationship between organizational power and ethical climate and ethical leadership. Organizational Power, Ethical Climate and Ethical Leadership Scale were applied to 529 academicians at Erzincan Binali Yıldirım University. SPSS 25 was used

$\left.{ }^{*}\right)$ Bu çalışma, Burcu Yoğurtcu'nun, Eskişehir Osmangazi Üniversitesi, Eğitim Bilimleri Enstitüsü, Eğitim Yönetimi Bilim Dalında Doç. Dr. Semra KIRANLI GÜNGÖR danışmanlığında hazırladığı ve 01.06.2021 tarihli savunulmuş ve başarılı bulunmuş yüksek lisans tez çalışmasından üretilmiştir.

**) Milli Eğitim Bakanlığı İngilizce Öğretmeni, Eğitim Yönetimi Bilim Uzmanı (e-posta: yogurtcuburcu@hotmail.com) (D) ORCID ID. https://orcid.org/ 0000-0001-5040-9478

***) Doç.Dr. Eskişehir Osmangazi Üniversitesi Eğitim Fakültesi Eğitim Bilimleri ABD EğitimYönetimi Bilim Dalı, (e-posta: semk2009@gmail.com), (D) ORCID ID.https://orcid.org/ 0000-0001-5785-8137

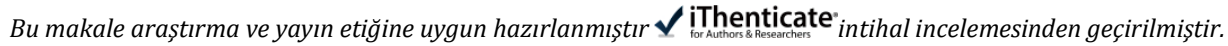


for the analysis of the data. Descriptive statistics, normal distribution, reliability test, t-test, ANOVA, correlation and multiple regression analyzes were performed. It was determined there is a positive significant relationship between organizational power, ethical climate and ethical leadership. It has been determined there is a positive significant relationship between reward, legitimate, expertise, charismatic power and knowledge power, ethical climate and ethical leadership. However, there has been no relationship between coercive power and ethical climate and ethical leadership. Charismatic, knowledge and expertise power predict ethical climate and ethical leadership. It is recommended administrators use charismatic, knowledge and expertise power effectively to increase academicians' perception of ethical climate and ethical leadership.

Keywords: Academician, Organizational Power, Ethical Climate, Ethical Leadership

Makale Gelis Tarihi: 15.06.2021

Makale Kabul Tarihi: 24.09.2021

DOI: 10.53487/ataunisosbil.953033

\section{Giriş}

Yaşam boyu meydana gelen değişimlerin insanlar üzerinde etkisi olduğu gibi kurumlar üzerinde de etkisi vardır. Bu değişimi yakalayabilmek için en önemli şey eğitimdir. Toplum olarak sahip olduğumuz eğitim sisteminin insan yetiştirme üzerindeki etkisi yadsınamaz bir gerçektir. Görevi bu kadar hassas olan eğitim ve eğitim kurumlarının yönetilmesi çok büyük önem taşımaktadır. Tarih boyunca insanların yönetme ve yönetilme eylemi yönetim kavramının eski bir bilim olduğunun bir göstergesidir (Bursalığlu, 2016: 1). Aydın'a (2018: 80) göre bir araya gelen insanları tespit edilen işleri yapmak için eyleme geçirme süreci yönetim olarak tanımlanır. Yöneticinin görev ve sorumluluğunda olan yönetme eylemi; yöneticinin var olan kaynağ 1 değerlendirip hedefe ulaşma çabasıdır. Yönetici bu çabayı güç kullanarak gerçekleştirmektedir. İnsanoğlunun hayatta kalma mücadelesinin temelini güç sistemi oluşturmaktadır. Güç, hayatın sürmesini sağlayan bebeklikten itibaren ulaşılmaya çalışılan bir gerçektir. Tüm insanlık, insanın temel güdüsü olan güç ile yönlendirilmektedir (Nietzsche, 2017: 358). Eski Mezopotamya'da yer alan kabile yöneticileri becerileri olanlar arasından seçilirken zamanla din adamlarının tanrılardan aldıkları güç ile yönetime geçtikleri görülmektedir (Bursalığlu, 2016: 12). Eski dönemlerde bile güce sahip olan insanların öncü ve söz sahibi oldukları göze çarpmaktadır.

Yöneticilerin çalışanlar üzerindeki etkisi, onları etkileyebilme gücü ve yetkileridir. Yöneticiler, sahip oldukları güç ve yetkileri çalışanlarının davranışlarını biçimlendirmek için kullanırlar (Özdemir, 2003: 160). Güç kavramının temeli, Socrates'e kadar uzanmaktadır. Güç, Sokrates'e göre insanları harekete geçiren şey; Platon'a göre devletin varlığı ve felsefe; Aristo'ya göre üstünlük ve yetenek sahibi olmak; Machiavelli'ye göre stratejiler; Nietzsche'ye göre ahlak; Hobbes'a göre temel ihtiyaç; Foucault'a göre gerçek; Weber'e göre kişinin kendi iradesini zorla kabul ettirmek, Lock'a göre iş bölümü, Rousseau'ya göre Tanrı; Kant'a göre erdem ve değerler tarafından yönetilen şey; Burke'ye göre akıldır (Cevizci, 2017: 63; Platon, 2010: 473). 
İnsanların veya grupların istenildiği yönde davranılmasının sağlanması örgütsel gücün olduğunun bir göstergesidir.

Örgütlerde yapılan işlerin verimli olması için verilen görev ve sorumlulukların etkili bir şekilde gerçekleştirilmesi gerekir ve örgüt çalışanlarından örgütün hedeflerine göre hareket etmesi beklenir. İş görenler; bilgi, beceri ve yaratıcı düşüncelerini örgüt için değerlendirirler. Çalışanların yönetilmesinde güç kullanılır ve bu şekilde örgüt işleyişi etkili olur. Örgütte başarıyı sağlayabilmek için doğru yönetilmek önem taşımaktadır (Gündüz, 2015: 1). Güç, örgütlerin ne yapacağına karar veren şeydir (Mintzberg, 1983: 36).

Örgütsel iklim algılamaları çalışanların motivasyonlarında, verimliliklerinde ve etkinliklerinde önemli bir yere sahiptir. Bu nedenle etik normları ve değerleri örgütün bünyesine dâhil etmenin bir yolu da etik iklim yapısını yerleştirmektir (Bilgen, 2014: 2). Örgütlerde güçlü ve olumlu bir etik iklim sağlamada rol ve model olan liderlerdir. Etik bir iklim oluşturularak, iş görenlerin yer aldıkları örgütü etik olarak idrak etmeleri, etik davranışlar sergilenmesi ve etik kararların alınmasını teşvik eder (Bulut, 2012: 2).

Liderin örgütün genel iklimi ve etik iklimi üzerinde etkisi vardır. Liderin, etik iklim üzerindeki etkililiği bireyin davranışını şekillendirerek genel etik iklimdeki olumsuz davranışları düzeltebilir (Peterson, 2002: 313). Kendi çalışanlarının yaptığı etik ya da etik dışı davranışların sorumluluğu örgüte aittir (Victor \& Culllen, 1988: 112). Lider, örgüt içerisindeki ilişkiyi güçlendirir. Yaşam koşullarımıza göre farklı liderlik türleri ile günümüzde karşı karşıya kalıyoruz. Bunlardan biri etik liderliktir. Etik liderlik, liderin örgütün amaçlarını geliştirirken mesleki etik ilkelere uyan davranışların sergilendiği bir liderlik çeşididir (Bulut, 2012: 1). Örgütün başarısı ve uzun süreli devamlılığı etik liderliğe bağlıdır (Mendonca, 2001: 270).

Etik liderin ilk olarak etik değer ve ilkelere sahip olması gerekir. Ayrıca, etik liderin davranışını gösterebileceği bir örgüt ortamına ihtiyacı vardır. Bir toplumu oluşturan bireylerin hayatlarının önemli bir kısmı örgütlerde geçmektedir. Yaşam kısaca örgütte ve örgütle yaşamdır (Aydın, 2018: 310). Bu açıklamalar göz önüne alındığında etik iklimin ve etik liderliğin örgütlerin temel yapı taşları olduğu görülmektedir. Örgütsel gücün de örgüt için önemi yadsınamaz bir gerçektir.

Yükseköğretim kurumları genel olarak güç mücadelelerinin açıkça hissedildiği toplumsal örgütler olarak nitelendirilir. Örgütlerdeki güç ilişkilerinin incelenmesi; güç ile baş etmenin öğrenilmesini, örgütte meydana gelen durumlara karşı farkındalık oluşturulmasını, örgüt iklimine bakış açısını ortaya çıkaran, örgütteki ilişkileri ve durumları fark etmede önemli rol oynadığ1 düşünülmektedir (Russel, 1990; Mintzberg, 1985; Scott, 1995; Murray \& Gandz, 1980). Bourdieu (1988) Homo Academicus adlı çalışmasında yükseköğretim kurumlarını kültürel ve sermaye sahibi olan bireylerin güç ve iktidar mücadelesi verilen bir alt alan olarak belirtilmektedir. Akademisyenler üniversitelerdeki güç ve iktidar ilişkileri ve bunun yansımalarından doğal olarak etkilenmektedirler. Bu durumda yöneticilerin gücü doğru yönetmek için kurumda etik iklim oluşturması ve etik liderlik göstermeleri gereklidir. 
Bu çalışmada örgütsel gücün; etik liderlik ve etik iklim ile ilişkisi, mevcut durum ortaya konulmaya çalışılmıştır. Yapılan bu çalışma ile yöneticilerin sorunları fark edebilmesine ve sorunların oluşmasına sebep olan durumları ortadan kaldırarak doğru kararlar verebilmesine önemli ölçüde katkı sağlayacağı beklenmektedir. Bu araştırma örgütsel güç, etik iklim ve etik liderlik konusunda yöneticilerin ve akademisyenlerin yeterli bilgiye ve farkındalığa sahip olup olmadıklarını saptamak açısından da önem taşımaktadır. Akademisyenler tarafından algılanan etik iklim ve etik liderlik ile birlikte yöneticiler kurumlarındaki işleyiş hakkında da fikir sahibi olabileceklerdir.

\section{Yöntem}

\section{A. Araştırma Deseni}

$\mathrm{Bu}$ çalışma, 2019-2020 eğitim-öğretim yılında Erzincan Binali Yıldırım Üniversitesi'nde görev yapan akademisyenlerin algılarına göre örgütsel gücün etik iklim ve etik liderlik ile ilişskisini konu almıştır. Nicel araştırma yöntemlerinden ilişkisel tarama modeli kullanılmıştır. Bir grubun belirgin özelliklerini ortaya çıkarmak için verilerin toplanmasını sağlayan çalışmalar tarama araştırmasıdır (Büyüköztürk, Çakmak-Kılıç, Akgün, Karadeniz ve Demirel, 2018: 15).

\section{B. Evren ve Örneklem}

Bu araştırmanın evrenini 2019-2020 eğitim-öğretim yılında Erzincan Binali Yıldırım Üniversitesi'nde çalışan 900 akademisyen oluşturmaktadır. Araştırmada yer alan akademisyenler İlahiyat, Hukuk, İktisadi ve İdari Bilimler, Eğitim, Tıp, Mühendislik, Eczacılık, Sağlık Bilimleri Fakültesi; Ali Cavit Çelebioğlu Sivil Havacılık Meslek Yüksekokulu, Beden Eğitimi ve Spor Yüksekokulu, Adalet Meslek Yüksekokulu, Turizm ve Otelcilik Meslek Yüksekokulu ve Meslek Yüksekokulu'nda görev yapmaktadir.

Örneklem, basit seçkisiz örnekleme yoluyla seçilmiştir. Büyüköztürk ve vd.'lerine (2018: 88) göre, evrende bulunan tüm birimler, örnekte yer almak için hem eşit hem de bağımsız bir şansa sahip olmaktadır. Basit seçkisiz örneklemin uygulanabilmesi için evren bilimlerinin bilinmesi ve listelenmesi önem taşımaktadır. Balcı'ya (2018: 100) göre bu tür örneklemede evrendeki her birim örneklem seçiminde eşit ve bağımsızdır. Çalışmanın örneklemi 547 kişiden oluşmaktadır. Ancak eksik veriler ve rastgele işaretlenmiş ölçekler analizden çıkarılmıştır. 529 kişiye ait olan veriler analize alınmıştır.

Örneklemde akademisyenlerin yer almasının sebepleri vardır. Çevremizde belirgin bir amaç için bir araya gelmiş, örgüt yapısı gösteren kurum ve kuruluşlar bulunmaktadır. Bunların içerisinde üniversitelerin önemi yadsınamaz bir gerçektir. $\mathrm{Bu}$ yapıların içerisinde akademisyenler önemli bir yere sahiptir. Akademisyenlik etik konusunun en çok üzerinde durulduğu, entelektüel gelişimin ön planda olduğu, yoğun çaba gerektiren, eğitim sürecinin hayat boyu devam ettiği ve toplumda saygınlığa sahip olan bir meslek grubudur. Üniversitelerin amaçları yönünde insanları mesleğe hazırlamak, bilim alanında araştırma yapmak ve topluma hizmet sunmak akademisyenlerin sorumluluklarındandır (Maya, 2013: 494). Araştırmaya katılan akademisyenlerin 
tanımlayıcı özelliklerini gösteren tablolar aşağıda verilmiştir. Araştırmaya katılan akademisyenlerin yaş, cinsiyet, unvan, eğitim durumu, bölüm ve hizmet süresi değişkenlerine göre frekans ve yüzde değerleri tespit edilmiştir.

\section{Veri Toplama Araçları}

$\mathrm{Bu}$ araştırmanın verileri nicel veri toplama araçları olan ölçek ile toplanmıştır. Araştırmada üç değişken bulunması sebebiyle veri toplama aracı olarak üç farklı ölçme aracı kullanılmıştır. Ölçek dört ayrı bölümden meydana gelmektedir. $\mathrm{Bu}$ bölümler katılımcı kişisel bilgileri, örgütsel güç ölçeği, örgütsel etik iklim ölçeği ve etik liderlik ölçeğidir. Bu araştırma için akademisyenlerin kişisel özelliklerini belirlemek amacıyla araştırmacı tarafından hazırlanan yedi sorudan meydana gelen kişisel bilgi formu kullanılmıştır. Bu kişisel bilgi formu akademisyenlerin kişisel özellikleri ile ilgili yaş, cinsiyet, unvan, eğitim durumu, branş, hizmet süresi gibi sorulardan oluşmaktadır.

\section{1. Örgütsel Güç Ölçeği}

Örgütsel Güç Ölçeği, Raven, Schwarzwald ve Koslowsky (1998) tarafindan geliştirilmiştir. C. H. Meydan (2010) tarafından Türkçe’ ye uyarlanmıştır. 33 soru ile altı boyutu ölçmek için yapılandırılmıştır. Ölçekteki sorular, 5'li Likert tipinde olup “(1) Hiç Katılmıyorum (2) Pek Katılmiyorum (3) Kararsızım (4) Katılıyorum (5) Tamamen Katılıyorum" şeklinde beş farklı aralıktan meydana gelmektedir. Puan aralıkları "1.00 1.80 Kesinlikle Katılmıyorum, 1.81 - 2.60 Katılmıyorum, 2.61 - 3.40 Kararsızım, 3.41 - 4.20 Katılıyorum, 4.21 - 5.00 Kesinlikle Katılıyorum” şeklindedir.

Araştırmaya katılan akademisyenlere bağlı oldukları en yakın üst yöneticiyi düşünerek ölçeklere yanıt vermeleri istenmiştir. Türkçe' ye Meydan (2010) tarafından uyarlanan ölçek altı boyutlu yapıdan meydana gelmektedir. Bu boyutlar ödüllendirme gücü, zorlayıcı güç, meşru güç, uzmanlık gücü, karizmatik güç ve bilgiye dayalı güçtür. Boyutların güvenilirlikleri sirasıyla $0,78,0,77,0,73,0,79,0,68$ ve 0,79 olduğu saptanmıştır. Ölçeğin tamamı için güvenilirlik katsayısı 0,83 olarak saptanmıştır.

\section{2. Örgütsel Etik İklim Ölçeği}

Örgütsel Etik İklim Ölçeği; Cullen, Victor ve Bronson (1993) tarafından geliştirilmiştir. Türkçe' ye Özen ve Durkan (2016) tarafından uyarlanmıştır. Beşli likert tipindedir, katılım düzeyleri $1=$ tamamen yanlış, $2=$ çoğu zaman yanlış, $3=$ Bazen doğru, 4 = Çoğu zaman doğru, 5 = Her zaman doğru olarak derecelendirilmiştir. Puan aralıkları "1.00 - 1.80 Tamamen yanlış, 1.81 - 2.60 Çoğu zaman yanlış, 2.61 - 3.40 Bazen doğru, 3.41 - 4.20 Çoğu zaman doğru, 4.21 - 5.00 Her zaman doğru” şeklindedir.

Türkçe' ye Özen ve Durkan (2016) tarafından uyarlanan Örgütsel Etik İklim Ölçeği 22 soru ve beş boyuttan oluşmaktadır. Ölçek alt boyutları sosyal sorumluluk, kurallılık, çıkarcı yardımseverlik, ilkelilik ve verimlilik olarak adlandırılmıştır. Boyutların güvenilirlik katsayısı sorumluluk için 0.83 , kurallılık için 0.78 , çıkarcı yardımseverlik için 0.71 , ilkelilik için 0.71 ve verimlilik için 0.72 saptanmıştır. Güvenilirlik katsayısı tüm ölçek için 0.87 olarak tespit edilmiştir. Ters madde ölçekte yer almamaktadır. 


\section{Etik Liderlik Ölçeği}

Etik davranışları ölçmek amacıyla Brown, Trevino ve Harrison (2005) tarafindan geliştirilmiş olan etik liderlik ölçeği Türkçe' ye Tuna, Bircan ve Yeşiltaş (2012) tarafından uyarlanmıştır. Tek boyutlu bir ölçme aracıdır. 10 maddeden oluşan bu ölçme aracı 1) Kesinlikle katılmıyorum, 2) Katılmıyorum, 3) Fikrim Yok, 4) Katılıyorum, 5) Kesinlikle katılıyorum ifadelerinden oluşan 5' li likert ölçeğidir. Puan aralıkları "1.00 1.80 Kesinlikle Katılmıyorum, 1.81 - 2.60 Katılmıyorum, 2.61 - 3.40 Kararsızım, 3.41 - 4.20 Katılıyorum, 4.21 - 5.00 Kesinlikle Katılıyorum” şeklindedir. Ölçeğin güvenirlilik katsayısı 0,88 olarak saptanmıştır.

Tablo 1. Örgütsel Güç, Etik İklim ve Etik Liderlik Ölçeklerinin Güvenirlik Katsayısı

\begin{tabular}{lcc}
\hline Ölçek & Cronbachs' Alpha & Madde sayısı \\
\hline Örgütsel Güç Ölçeği &, 872 & 33 \\
Etik İklim Ölçeği &, 900 & 22 \\
Etik Liderlik Ölçeği &, 950 & 10 \\
\hline
\end{tabular}

Tablo 1'e göre ÖGÖ $\alpha=, 872$ düzeyinde güvenirliğe sahip olduğu saptanmıștır. Bu değere göre ÖGÖ’nin tümü "İyi” düzeyde güvenilir olduğu ifade edilebilir. EİÖ $\alpha=900$ düzeyinde bir güvenirliğe sahip olduğu saptanmıştır. Bu değere göre Etik İklim Ölçeği’ nin tümünün “Mükemmel” düzeyde güvenilir olduğu belirtilebilir. ELÖ’nin güvenirlik katsayısı $\alpha=, 950$ olarak tespit edilmiştir. Elde edilen bu sonuca göre Etik Liderlik Ölçeği'nin “Mükemmel” düzeyde güvenilir olduğu söylenebilir.

\section{Verilerin Toplanması}

Araştırmadaki veriler 2019-2020 güz akademik yılında EBYÜ’de görev yapan akademisyenlerden toplanmıştır. Araştırmada kullanılan ölçekler dağıtılmadan önce ölçek izinleri ölçek sahiplerinden, etik izin etik kurallar çerçevesinde ESOGÜ’den ve araştırma izni de EBYÜ’den alınmıştır.

Fen edebiyat fakültesi haricinde 700 akademisyene ölçek elden dağıtılmıştır. Birçok kez gidilmesine rağmen yerinde olmayan, izinli olan, yurt dışında olan akademisyenlere ulaşılamamıştır. Geriye elden toplanan ölçek sayısı 547'dir.

\section{E. Verilerin Çözümlenmesi}

$\mathrm{Bu}$ çalışmada elde edilen veriler sonucunda istatistiksel analizler yapılmıştır ve bulgulara ulaşılmıştır. Verilerin değerlendirilmesinde SPSS 25.0 istatistik programı kullanılmıştır. Akademisyenlerin tanımlayıcı özelliklerini belirlemek için betimsel istatistiklerden faydalanılmıştır. Akademisyenlerin örgütsel güç ile ilgili görüşleri, etik iklim ve etik liderlik düzeyleri arasındaki ilişkinin düzeyinin belirlenmesi için 
korelasyon analizine başvurulmuştur. Araştırmadaki değişkenlerin birbirlerini etkileme durumunu belirtmek için çoklu regresyon analizi yapılmıştır.

\section{Bulgular}

\section{A. Akademisyenlerin Örgütsel Güç Algılarına Yönelik Bulgular}

Araştırmanın bu bölümünde, katılımcıların yöneticilerin kullandıkları güç türleri ile ilgili algılarını ve seviyelerini belirlemek için araştırmada yer alan değişkenlere ilişkin standart sapma ve aritmetik ortalama bulguları sunulmuştur (Tablo 2).

Tablo 2. Örgütsel Güç Ölçeği ve Boyutlarına Ait Standart Sapma ve Aritmetik Ortalama Değerleri

\begin{tabular}{lcl}
\hline Ölçek ve Alt Boyutları & $\overline{\mathrm{x}}$ & SS \\
\hline Örgütsel Güç & 3,21 & 0,51 \\
Ödül Gücü & 3,11 & 0,65 \\
Zorlayıcı Güç & 3,32 & 0,69 \\
Meşru Güç & 3,32 & 0,47 \\
Uzmanlık Gücü & 2,91 & 0,89 \\
Karizmatik güç & 3,19 & 0,81 \\
Bilgiye Dayalı Güç & 3,40 & 0,62 \\
\hline
\end{tabular}

Tablo 2'ye göre örgütsel güç ve boyutlarına ait standart sapma ve aritmetik ortalama değerleri görülmektedir. Yöneticilerin kullandıkları güç türleri incelendiğinde bilgiye dayalı güç “yüksek”, diğer güç türlerini “orta” düzeyde algıladıkları görülmektedir.

\section{B. Akademisyenlerin Etik İklim Algılarına Yönelik Bulgular}

Araştırmanın bu bölümünde, katılımcıların etik iklim ile ilgili algılarını ve seviyelerini belirlemek için araştırmada yer alan değişkenlere ilişkin standart sapma ve aritmetik ortalama bulguları sunulmuştur (Tablo 3).

Tablo 3. Etik İklim Ölçeği ve Boyutlarına Ait Standart Sapma ve Aritmetik Ortalama Değerleri

\begin{tabular}{lcc}
\hline Ölçek ve Alt Boyutları & $\overline{\mathrm{X}}$ & SS \\
\hline Sosyal sorumluluk & 3,50 &, 73008 \\
Kurallılık & 3,89 &, 79244 \\
Çıkarcı yardımseverlik & 3,21 &, 61582 \\
İlkelilik & 2,90 &, 66201 \\
Verimlilik & 3,49 &, 79271 \\
Ė̈Ö Toplam & 3,41 &, 55504 \\
\hline
\end{tabular}


Tablo 3 incelendiğinde etik iklim ölçeği ve boyutlarına ait standart sapma ve aritmetik ortalama değerleri görülmektedir. Boyutların aritmetik ortalama ve standart sapma değerleri incelendiğinde katılımcıların etik iklimi, verimliliği, kurallılığı ve sosyal sorumluluğu "katılıyorum" düzeyinde, ilkeliliği ve çıkarcı yardımseverliği "kararsızım" düzeyinde algıladıkları görülmektedir.

\section{Akademisyenlerin Etik Liderlik Algılarına Yönelik Bulgular}

Araştırmanın bu bölümünde, katılımcıların yöneticilerin kullandıkları etik liderlik ile ilgili algılarını ve seviyelerini belirlemek için araştırmada yer alan değişkenlere ilişkin standart sapma ve aritmetik ortalama bulguları sunulmuştur (Tablo 4).

Tablo 4. Etik Liderlik Ölçeğine Ait Standart Sapma ve Aritmetik Ortalama Değerleri

\begin{tabular}{lll}
\hline Ölçek & $\overline{\mathrm{X}}$ & SS \\
\hline Etik Liderlik & 3,28 &, 93 \\
\hline
\end{tabular}

Tablo 4'e göre etik liderlik ölçeğine ait standart sapma ve aritmetik ortalama değerleri görülmektedir. Araştırmadaki örneklemi oluşturan akademisyenlerin yöneticilerin kullandıkları etik liderlik algıları "orta” düzeyde görülmektedir.

\section{D. Örgütsel Güç, Etik İklim ve Etik Liderlik Arasındaki İlişkilere Dair \\ Bulgular}

Örgütsel güç ile etik iklim ve etik liderlik arasındaki ikili ilişkileri ortaya çıkarmak için yapılan Pearson Korelasyon Analizi sonucuna göre bulunan korelasyon katsayısı değerleri; . $10 \leq \mathrm{r}<.30$ şeklindeyse düşük seviyede ilişki, . $30 \leq \mathrm{r}<50$ şeklindeyse orta seviyede ilişki, $r \geq .50$ şeklindeyse yüksek seviyede ilişki (Field, 2013: 133) vardır denilmektedir. Tablo 5 'te gerçekleştirilen korelasyon analizi sonuçları gösterilmiştir.

Tablo 5. Örgütsel Güç, Etik İklim ve Etik Liderlik Arasındaki İlişkiler

\begin{tabular}{|c|c|c|c|c|c|c|c|}
\hline 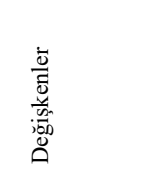 & 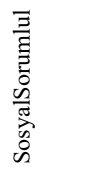 & $\begin{array}{l}\text { 兰 } \\
\bar{\Xi} \\
\stackrel{\Xi}{\Xi}\end{array}$ & 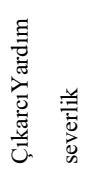 & 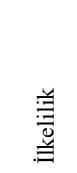 & 䄅 & 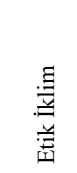 & 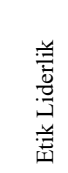 \\
\hline Ödül Gücü &, $296^{* *}$ &, $269^{* *}$ &, $318^{* *}$ &, $279^{* *}$ &, $215^{* *}$ &, $360^{* *}$ &, $416^{* *}$ \\
\hline Zorlayıcı Güç &,- 032 &, 023 &, $119^{* *}$ &,- 027 &,- 065 &,- 002 &, 001 \\
\hline Meşru Güç &, $265^{* *}$ &, $252^{* *}$ &, $330^{* *}$ &, $236^{* *}$ &, $232^{* *}$ &, $339^{* * *}$ &, $364^{* *}$ \\
\hline Uzmanlık Güç &, $326^{* *}$ &, $376^{* *}$ &, $286^{* *}$ &, $243^{* *}$ &, $328^{* *}$ &, $408^{* *}$ &, $520^{* *}$ \\
\hline Karizmatik Güç &, $456^{* *}$ &, $391^{* *}$ &, $293^{* *}$ &, $365^{* *}$ &, $358^{* *}$ & $.500^{* *}$ & ,634** \\
\hline
\end{tabular}


Bir Yükseköğretim Kurumunda Örgütsel Gücün Etik İklim ve Etik Liderlik ile İlişkisi

\begin{tabular}{|c|c|c|c|c|c|c|c|}
\hline Bilgi Gücü &, $383^{* *}$ &, $365^{* *}$ &, $278^{* *}$ &, $348^{* *}$ &, $316^{* *}$ &, $448^{* *}$ &, $519^{* *}$ \\
\hline Örgütsel Güç &, $391^{* *}$ & $390^{* *}$ &, $364^{* *}$ &, $329^{* *}$ &, $322^{* *}$ &, $472^{* *}$ &, $571^{* *}$ \\
\hline
\end{tabular}

Ödül gücü ile çıkarcı yardımseverlik $(\mathrm{r}=.318, \mathrm{p}<.01)$, etik iklim $(\mathrm{r}=.360, \mathrm{p}<.01)$ ve etik liderlik $(\mathrm{r}=.416, \mathrm{p}<.01)$ arasında olumlu ve orta seviyede anlamlı bir ilişkinin olduğu saptanmıştır. Ödül gücü ile sosyal sorumluluk $(\mathrm{r}=.296, \mathrm{p}<.01)$, kurallılık $(\mathrm{r}=.269, \mathrm{p}<.01)$, ilkelilik $(\mathrm{r}=.279, \mathrm{p}<.05)$ ve verimlilik $(\mathrm{r}=.215, \mathrm{p}<.01)$ arasında olumlu ve düşük düzeyde anlamlı ilişki bulunmaktadır.

Zorlayıcı güç ile çıkarcı-yardımseverlik $(r=.119, \mathrm{p}<.01)$ arasında olumlu ve düşük düzeyde anlamlı bir ilişki görülürken zorlayıcı güç ile sosyal sorumluluk $(\mathrm{r}=-.032$, $\mathrm{p}>.01)$, kurallılık $(\mathrm{r}=.023, \mathrm{p}>.01)$, ilkelilik $(\mathrm{r}=-.027, \mathrm{p}>.01)$, verimlilik $(\mathrm{r}=-.065, \mathrm{p}>.01)$, etik iklim $(\mathrm{r}=-.002, \mathrm{p}>.01)$ ve etik liderlik $(\mathrm{r}=.001, \mathrm{p}>.01)$ arasında herhangi bir ilişki tespit edilmemiştir.

Meşru güç ile çıkarcı yardımseverlik ( $r=.330, \mathrm{p}<.01)$, etik iklim $(\mathrm{r}=339, \mathrm{p}<.01)$ ve etik liderlik $(\mathrm{r}=.364, \mathrm{p}<.01)$ arasında olumlu yönde orta seviyede anlamlı ilişki görülmektedir. Ayrıca, meşru güç ile sosyal sorumluluk $(\mathrm{r}=.265, \mathrm{p}<.01)$, kurallılık $(\mathrm{r}=.252, \mathrm{p}<.01)$, ilkelilik $(\mathrm{r}=.236, \mathrm{p}<.01)$ ve verimlilik $(\mathrm{r}=.232, \mathrm{p}<.01)$ arasinda olumlu ve düşük düzeyde anlamlı bir ilişki tespit edilmiştir.

Uzmanlık gücü ile sosyal sorumluluk $(r=.326, p<.01)$, kurallılık $(r=.376, p<.01)$ ve verimlilik $(\mathrm{r}=.328, \mathrm{p}<.01)$ arasında olumlu ve orta düzeyde anlamlı bir ilişkinin olduğu fakat uzmanlık gücü ile çıkarcı yardımseverlik $(\mathrm{r}=.286, \mathrm{p}<.01)$ ve ilkelilik $(\mathrm{r}=.243$, $\mathrm{p}<.01$ ) arasında olumlu ve düşük düzeyde anlamlı bir ilişkinin olduğu görülmektedir.

Karizmatik güç ile etik liderlik $(\mathrm{r}=.634, \mathrm{p}<.01)$ ve etik iklim $(\mathrm{r}=.500, \mathrm{p}<.01)$ arasında olumlu ve yüksek seviyede anlamlı bir ilişki görülürken sosyal sorumluluk $(\mathrm{r}=.456$, $\mathrm{p}<.01)$, kurall111k $(\mathrm{r}=.391, \mathrm{p}<.01)$, ilkelilik $(\mathrm{r}=.365, \mathrm{p}<.01)$ ve verimlilik $(\mathrm{r}=.358, \mathrm{p}<.01)$ arasında olumlu ve orta seviyede anlamlı bir ilişki olduğu tespit edilmiştir. Ayrıca, karizmatik güç ile çıkarcı yardımseverlik $(r=.293, p<.01)$ arasında olumlu yönlü düşük seviyedeki ilişkinin anlamlı olduğu görülmektedir.

Bilgi gücü ile sosyal sorumluluk $(\mathrm{r}=.383, \mathrm{p}<.01)$, kurallılık $(\mathrm{r}=.365, \mathrm{p}<.01)$, ilkelilik $(\mathrm{r}=.348, \mathrm{p}<.01)$, verimlilik $(\mathrm{r}=.316, \mathrm{p}<.01)$ ve etik iklim $(\mathrm{r}=.448, \mathrm{p}<.01)$ arasinda olumlu ve orta seviyede anlamlı bir ilişki görülürken çıkarcı yardımseverlik $(r=.278, p<.01)$ ile arasında olumlu ve düşük seviyede ilişkinin anlamlı olduğu saptanmıştır.

Örgütsel güç ile etik liderlik arasında olumlu ve yüksek düzeyde bir ilişki bulunmaktadır $(\mathrm{r}=.571, \mathrm{p}<.01)$. Örgütsel güç ile sosyal sorumluluk $(\mathrm{r}=.391, \mathrm{p}<.01)$, kurallılık $(\mathrm{r}=.390, \mathrm{p}<.01)$, çıkarcı yardımseverlik $(\mathrm{r}=.364, \mathrm{p}<.01)$, etik iklim $(\mathrm{r}=.472$, $\mathrm{p}<.01)$ ilkelilik $(\mathrm{r}=.329, \mathrm{p}<.01)$ ve verimlilik $(\mathrm{r}=.322, \mathrm{p}<.01)$ arasında olumlu ve orta düzeyde bir ilişkinin anlamlı olduğu görülmektedir.

Örgütsel gücün etik iklim ve etik liderlik düzeylerini ne oranda yordadığını belirlemek amacıyla çoklu regresyon analizleri yapılmıştır. Örgütsel gücün etik liderlik 
değişkenini ne oranda yordadığını belirlemek amacıyla yapılan adımsal regresyon sonuçları Tablo 6'da sunulmuştur.

Tablo 6. Örgütsel Gücün Etik Liderliği Yordamasına İlişkin Adımsal Regresyon Sonuçları

\begin{tabular}{|c|c|c|c|c|c|c|c|}
\hline \multirow[b]{2}{*}{ Model } & \multicolumn{2}{|c|}{$\begin{array}{l}\text { Standardize } \\
\text { edilmemiş }\end{array}$} & $\begin{array}{r}\text { Standardize } \\
\text { edilmiş }\end{array}$ & \multirow[b]{2}{*}{$\mathrm{t}$} & \multirow[b]{2}{*}{$\mathrm{p}$} & \multirow[b]{2}{*}{ Tolerans } & \multirow[b]{2}{*}{ VIF } \\
\hline & $\mathrm{B}$ & $\begin{array}{l}\text { S.Hat } \\
\text { a }\end{array}$ & $\beta$ & & & & \\
\hline 1. (sabit) & 949 & ,128 & & 7,417 & ,000 & & \\
\hline $\begin{array}{l}\text { Karizmatik } \\
\text { güç }\end{array}$ &, 731 &, 039 & 634 & 18,823 &, 000 & 1,000 & 1,000 \\
\hline 2. (sabit) & 253 & ,173 & & 1,461 & ,145 & & \\
\hline $\begin{array}{l}\text { Karizmatik } \\
\text { güç }\end{array}$ &, 578 &, 046 &, 501 & 12,538 &, 000 & 669 & 1,495 \\
\hline Bilgi Gücü &, 349 &, 060 &, 231 & 5,772 &, 000 & ,669 & 1,495 \\
\hline 3. (sabit) & 213 & ,171 & & 1,249 & 212 & & \\
\hline $\begin{array}{c}\text { Karizmatik } \\
\text { Güç }\end{array}$ & ,478 &, 052 & ,415 & 9,248 &, 000 &, 516 & 1,936 \\
\hline Bilgi Gücü &, 303 &, 061 & ,200 & 4,986 &, 000 & ,645 & 1,550 \\
\hline $\begin{array}{l}\text { Uzmanlık } \\
\text { Gücü }\end{array}$ &, 177 &, 044 &, 169 & 4,037 &, 000 &, 596 & 1,677 \\
\hline \multicolumn{4}{|c|}{ 1. R: .634, $\mathrm{R}^{2}: .402, \mathrm{~F}_{(1-527)}=354,297, \mathrm{p}<.001$} & $\mathrm{p}<.001$ & & & \\
\hline \multicolumn{4}{|c|}{ 2. $\mathrm{R}: .662, \mathrm{R}^{2}: .438, \mathrm{~F}_{(2-526)}=204,666, \mathrm{p}<.001$} & \multirow{2}{*}{\multicolumn{2}{|c|}{ Durbin-Watson: 1,772 }} & & \\
\hline \multicolumn{4}{|c|}{ 3. R: .674, $\mathrm{R}^{2}: .455, \mathrm{~F}_{(3-525)}=145,847, \mathrm{p}<.001$} & & & & \\
\hline
\end{tabular}

Yapılan regresyon analizinin sonuçları Tablo 6'da verilmiştir. Adımsal regresyon modelinin anlamlılığına yönelik tek yönlü ANOVA testi sonuçları; karizmatik güç, bilgi gücü ve uzmanlık gücü dahil edilerek kurulan regresyon modelinin anlamlı olduğunu göstermektedir $(\mathrm{F}(3-525)=145,847, \mathrm{p}<.001)$.

Tablo 6'ya göre adımsal regresyon modelinin birinci aşamasında; incelenen karizmatik gücün, etik liderliği yordamadaki katsayısı .731 olup, beta katsayısının anlamlılığına ilişkin $\mathrm{t}$ testi sonuçları anlamlı bulunmuştur $(\mathrm{t}=18,823 ; \mathrm{p}<.001)$. Karizmatik gücün etik liderliğin \%40,2'sini açıkladığı görülmektedir (R: .634, R2: .402, $\mathrm{F}(1-527)=354,297, \mathrm{p}<.001)$.

Adımsal regresyon analizinin ikinci aşamasında; modele karizmatik gücün yanı sıra bilgi gücü de eklenmiştir. Modeldeki diğer değişkenler sabit tutulduğunda karizmatik 
gücün beta katsayısı .578; bilgi gücünün beta katsayısı .349 olup, beta sayısının anlamlılığına ilişkin t testi sonuçları anlamlı bulunmuştur (tkarizmatik güç = 12.538; $\mathrm{p}<.001 /$ tbilgi gücü=5,772; $<<.001$ ). Buna göre karizmatik güç ve bilgi gücü birlikte etik liderliğin \%43,8'ini açıklamaktadır (R: .662, R2: .438, F $(2-526)=204,666, p<.001)$.

Adımsal regresyon analizinin üçüncü aşamasında; modele karizmatik güç ve bilgi gücünün yanına uzmanlık gücü de dahil edilmiştir. Modeldeki diğer değişkenler sabit tutulduğunda karizmatik gücün beta katsayısı .478; bilgi gücünün beta katsayısı .303; uzmanlık gücünün beta katsayısı .177 olup, beta sayısının anlamlılığına ilişkin t testi sonuçları anlamlı bulunmuştur (tkarizmatik güç = 9.248; $\mathrm{p}<.001 /$ tbilgi gücü= 4,986; $\mathrm{p}<.001$ / tuzmanlık gücü=4,037; $\mathrm{p}<.001$ ). Karizmatik güç, bilgi gücü ve uzmanlık gücünün birlikte etik liderliğin \%46'sını açıkladığı belirlenmiştir (R: .674, R2: .45,5, F $(3-525)=145,847, \mathrm{p}<.001)$. Dolayısıyla; karizmatik güç, bilgi gücü ve uzmanlık gücü etik liderliği pozitif yönde etkilediği sonucuna varılmaktadır.

Örgütsel gücün etik liderliği açıklamaya ilişkin en etkili değişkenin karizmatik güç, en az etkili değişkenin ise uzmanlık gücü olduğu görülmektedir. Başka bir ifadeyle yordayıcı değişkenlerin etik liderlik üzerindeki göreli önemi sırasıyla karizmatik güç, bilgi gücü ve uzmanlık gücü olduğu belirlenmiştir.

Örgütsel gücün etik iklim değişkenini ne oranda yordadığını belirlemek amacıyla yapılan adımsal regresyon sonuçları Tablo 7'de sunulmuştur.

Tablo 7. Örgütsel Gücün Etik İklimi Yordamasına İlişkin Adımsal Regresyon Sonuçları

\begin{tabular}{|c|c|c|c|c|c|c|c|c|}
\hline \multirow[b]{2}{*}{ Model } & \multicolumn{2}{|c|}{ Standardize edilmemiş } & $\begin{array}{r}\text { Standardize } \\
\text { edilmiş }\end{array}$ & \multirow{2}{*}{\multicolumn{2}{|c|}{$\mathrm{t}$}} & \multirow[b]{2}{*}{$\mathrm{p}$} & \multirow[b]{2}{*}{ Tolerans } & \multirow[b]{2}{*}{ VIF } \\
\hline & $\mathrm{B}$ & S.Hata & $\beta$ & & & & & \\
\hline 1. (sabit) & 2,313 &, 085 & & 27,117 & &, 000 & & \\
\hline $\begin{array}{c}\text { Karizmatik } \\
\text { güç }\end{array}$ & ,343 &, 026 &, 500 & 13,262 & &, 000 & 1,000 & 1,000 \\
\hline 2. (sabit) & 1,884 &, 116 & & 16,251 & &, 000 & & \\
\hline $\begin{array}{l}\text { Karizmatik } \\
\text { güç }\end{array}$ & ,249 &, 031 &, 363 & 8,068 & &, 000 & ,669 & 1,495 \\
\hline BilgiGücü &, 215 &, 040 &, 239 & 5,309 & &, 000 & ,669 & 1,495 \\
\hline 3. (sabit) & 1,867 &, 116 & & 16,161 & &, 000 & & \\
\hline $\begin{array}{c}\text { Karizmatik } \\
\text { Güç }\end{array}$ &, 207 &, 035 &, 302 & 5,938 & &, 000 &, 516 & 1,936 \\
\hline Bilgi Gücü & ,196 &, 041 &, 217 & 4,770 & &, 000 & ,645 & 1,550 \\
\hline $\begin{array}{r}\text { Uzmanlık } \\
\text { Gücü }\end{array}$ &, 074 &, 030 &, 118 & 2,482 & &, 013 &, 596 & 1,677 \\
\hline
\end{tabular}

1. R: .500, $\mathrm{R}^{2} . .250, \mathrm{~F}_{(1-527)}=175,878, \mathrm{p}<.001$

$.001^{\mathrm{p}<} \quad<.05^{\mathrm{p}}$




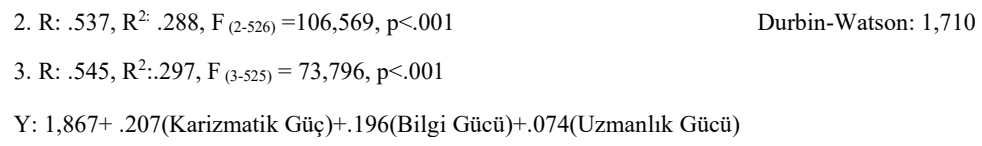

Yapılan regresyon analizinin sonuçları Tablo 7'de verilmiştir. Adımsal regresyon modelinin anlamlılığına yönelik tek yönlü ANOVA testi sonuçları; karizmatik güç, bilgi gücü ve uzmanlık gücü dahil edilerek kurulan regresyon modelinin anlamlı olduğunu göstermektedir $(\mathrm{F}(3-525)=73,796, \mathrm{p}<.001)$.

Tablo 7'ye göre adımsal regresyon modelinin birinci aşamasında; incelenen karizmatik gücün, etik iklimi yordamadaki katsayısı 343 olup, beta katsayısının anlamlılı̆ı̆na ilişkin $\mathrm{t}$ testi sonuçları anlamlı bulunmuştur $(\mathrm{t}=13,262 ; \mathrm{p}<.001)$. Karizmatik gücün etik iklimin \%25'ini açıkladığı görülmektedir (R: .500, R2: .250, F (1527) $=175.878, \mathrm{p}<.001)$.

Adımsal regresyon analizinin ikinci aşamasında; modele karizmatik gücün yanı sıra bilgi gücü de eklenmiştir. Modeldeki diğer değişkenler sabit tutulduğunda karizmatik gücün beta katsayısı .249; bilgi gücünün beta katsayısı .215 olup, beta sayısının anlamlılı̆ına ilişkin $\mathrm{t}$ testi sonuçları anlamlı bulunmuştur (tkarizmatik güç = 8.068; $\mathrm{p}<.001 /$ tbilgi gücü $=5.309 ; \mathrm{p}<.001)$. Buna göre karizmatik güç ve bilgi gücü birlikte etik iklimin \%29'unu açıklamaktadır (R: .537, R2: .288, F(2-526) =106,569, p<.001).

Adımsal regresyon analizinin üçüncü aşamasında; modele karizmatik güç ve bilgi gücünün yanına uzmanlık gücü de dahil edilmiştir. Modeldeki diğer değişkenler sabit tutulduğunda karizmatik gücün beta katsayıs1 .207; bilgi gücünün beta katsayıs1 .196; uzmanlık gücünün beta katsayısı .074 olup, beta sayısının anlamlılığına ilişkin $t$ testi sonuçları anlamlı bulunmuştur (tkarizmatik güç $=5,938 ; \mathrm{p}<.001 /$ tbilgi gücü= 4.770; $\mathrm{p}<.001 /$ tuzmanlık gücü $=2.482 ; \mathrm{p}<.001)$. Karizmatik güç, bilgi gücü ve uzmanlık gücünün birlikte etik iklimin \%30'unu açıkladığı belirlenmiştir (R: .545, R2: .297, F (3$525)=73,796, p<.001)$. Dolayısıyla karizmatik güç, bilgi gücü ve uzmanlık gücü etik iklimi pozitif yönde etkilediği sonucuna varılmaktadır.

Örgütsel gücün etik iklimi açıklamaya ilişkin en etkili değişkenin karizmatik güç, en az etkili değişkenin ise uzmanlık gücü olduğu görülmektedir. Başka bir ifadeyle yordayıcı değişkenlerin etik iklim üzerindeki göreli önemi sırasıyla karizmatik güç, bilgi gücü ve uzmanlık gücü olduğu belirlenmiştir.

\section{Sonuç ve Tartışma}

$\mathrm{Bu}$ araştırma, örgütsel gücün etik iklim ve etik liderlik ile ilişkisini ortaya koymayı hedeflemiştir. Bu araştırmanın sınırlılıkları 2019-2020 Eğitim- Öğretim yılı içerisinde Erzincan Binali Yıldırım Üniversitesi'nde çalışmakta olan akademisyenler ve Örgütsel Güç Ölçeği (Meydan, 2010), Etik İklim Ölçeği (Cullen, Victor \& Bronson, 1993) ve Etik Liderlik Ölçeği (Brown, Trevino \& Harrison, 2005) içerisinde bulunan sorular çerçevesindedir. Alan yazına bakıldığında yurt içi ve yurt dışında yapılan bu türde üç değiş̧enin birlikte ele alındığı bir çalışmaya rastlanmamıştır. Bu değişkenlerin farklı 
gruplarla yer aldığı araştırmalar bulunmaktadır. Bu araştırma, akademisyenlerin algılarına göre örgütsel gücün etik iklim ve etik liderlik ile ilişkisini belirterek, araştırmanın sonunda ortaya çıkan sonuçlarla önceden yapılan araştırmaları karşılaştırıp açıklayarak alan yazına katkı sağlayacaktır.

Araştırmada yer alan akademisyenlerin, yöneticilerin kullandıkları tüm güç türlerini "orta" düzeyde algıladıkları görülmektedir. Yöneticiler en çok bilgiye dayalı gücü kullanmaktadır. En az kullanılan güç türü uzmanlık gücü olarak ortaya çıkmıştır. Akademisyenlerin yöneticilerinin kullandıkları güç türlerini orta düzeyde algılamaları; Yılmaz ve Altınkurt (2012); Meydan'ın (2010) araştırmalarıyla benzerlik göstermektedir. Güç türlerinin orta düzeyde algılanması ile bu araştırma Cömert'in (2014) araştırmasından farklıdır. Bu durum, yöneticilerinin örgütsel gücü pasif olarak ellerinde bulundurmadıklarından ve aynı zamanda bunu baskı unsuru olarak da görmediklerinden kaynaklanmış olabilir. Akademisyenlerin, yöneticilerinin örgütsel gücü demokratik bir şekilde kullandıkları söylenebilir.

Özcenay (2017) ve Polat’ın (2010) araştırmasında bilgiye dayalı gücün yüksek çıkmaması bu araştırmadan farklılık göstermektedir. Akademisyenlerin, yöneticilerinin kullandıkları örgütsel güç türleri içerisinde bilgiye dayalı gücün yüksek çıkması yükseköğretim kurumlarının bilgi temelli olup, bilgiyi arama çabasına dayalı akademik ortamdan kaynaklandığı söylenebilir. Bu bağlamda bilimsel çalışmaların yapıldığı üniversitelerde bilgiye dayalı gücün yüksek çıkmasının istenilen bir durum olduğu düşünülebilir.

Araştırmaya katılan akademisyenlerin etik iklim algılarının "yüksek" düzeyde olduğu görülmektedir. Araştırmaya katılan öğretim elemanlarının etik iklim algıları kurallılık, sosyal sorumluluk ve verimlilik açısından yüksek düzeyde olduğu görülmektedir. İlkelilik ve çıkarcı yardımseverlik açısından da orta düzeyde algıladıkları ortaya çıkmıştır. Öğretim elemanlarının çalıştıkları kurumdaki etik iklim algılarının yüksek olduğu bu çalışma ile Tokhay’ın (2016) çalışması benzer özellik göstermektedir. Kuyucu-Güzel (2019), Eyidoğan'ın (2013) ve Aydan (2017) çalışmasında etik iklim algısının orta düzeyde olması bu araştırma ile örtüşmemektedir. $\mathrm{Bu}$ durum akademisyenlerin çalıştıkları kurumda kurallara bağlılığa, işleri daha iyi yapmaya, birbirlerine yardım etmelerine ve yapılan faaliyetlerin toplumsal değerlerle ne kadar uyum sağladığına verdikleri önemden kaynaklanabilir.

Araştırmaya katılan akademisyenlerin, yöneticilerinin etik liderlik davranışlarını "orta" düzeyde algıladıkları görülmektedir. Örgütün yönetiminde yöneticilerin etik liderlik davranışı sergiledikleri görülmektedir. Akademisyenlerin yöneticilerinin etik liderlik davranışlarından etkilendiği anlaşılmaktadır. Özdemir'in (2015) araştırması akademisyenlerin etik liderlik algısının orta düzeyde olduğu ortaya çıkması bu araştırma ile örtüşmektedir. Buna göre araştırmanın yapıldığı kurumlardaki yöneticilerin çalışanlarını dinleyen, kişisel hayatında etik olan, adil ve dengeli karar verebilen, iş etiğine, değerlere sahip olan kişiler olduğu söylenebilir. Yöneticilerin çalışanların tutum ve davranışları üzerinde olumlu etkisi olduğunu göstermektedir. 
Araştırma sonucuna göre, örgütsel güç ile etik iklim ve etik liderlik arasında olumlu ve anlamlı bir ilişkinin olduğu tespit edilmiştir. Ödül gücü, meşru güç, uzmanlık gücü, karizmatik güç ve bilgi gücü ile etik iklim ve etik liderlik arasında olumlu ve anlamlı bir ilişkinin olduğu saptanmıştır. Ancak zorlayıcı güç ile etik iklim ve etik liderlik arasında herhangi bir ilişki tespit edilmemiştir.

Diş ve Ayık (2016) ve Decker (1989) yaptığı çalışmalarında örgütsel gücün etik iklimi olumlu yönde etkilemesi ile bu çalışmanın benzerlik gösterdiği görülmektedir. Yöneticilerin örgütsel güç içerisinde, ödül gücü, meşru güç, uzmanlık gücü, karizmatik güç ve bilgiye dayalı gücü doğru bir şekilde kullandıklarında hissettirdikleri etik liderlik algıları akademisyenlerin çalışma ortamındaki etik iklimi olumlu etkilediği görülmüş̧ür. Etik iklimin güçlü olması yöneticilerle akademisyenler arasındaki iletişimi güçlendireceğinden, akademisyenlerin çalışmalarını daha huzurlu bir ortamda yapmalarını sağlayabilir. Bu durum da yapılan çalışmaların daha verimli olmasını, çalışanların da daha üretken olmalarına imkân verebilir, çalışanların güven ortamını ve birbirlerine karşı olumlu davranışlar sergilemelerini sağlayabilir.

Zorlayıcı güç haricinde ödül gücü, meşru güç, uzmanlık gücü, karizmatik güç ve bilgi gücü ile etik liderlik arasında olumlu yönde ve anlamlı bir ilişki tespit edilmesi BustosVargas (2016) yaptı̆̆ 1 çalışma ile örtüşmektedir. Akademisyenlerin yöneticilerin zorlayıcı güce sahip olmalarından olumlu ya da olumsuz olarak etkilenmediği görülmektedir. Bunun yanı sıra yöneticinin ödül gücünü kullanması motivasyonu arttırdığını söyleyebiliriz. Yine akademisyenlerin yöneticilerinin bilgi ve becerilerinden etkilendiği ve saygı duyduğu görülmektedir. Akademisyenlerin etik liderlik algısında zorlayıcı güçlerin değil motive edici ve olumlu güçlerin etkili olduğu söylenebilir.

Örgütsel gücün alt boyutları birbirleriyle anlamlı ve olumlu yönde ilişkiye sahip olması ile bu çalışma Hinkin ve Schriesheim' in (1989) çalışmasından farklılık göstermektedir. Üniversitelerde ast ve üst ilişkileri yoğun hissedildiği için tüm güç türlerinin birbirleri ile anlamlı ilişkilere sahip olması diğer çalışmadan farklı olma sebebini açıklayabilir. Etik liderlikle etik iklim arasındaki anlamlı ilişkinin olması ile bu çalışma Jose ve Thibodeaux (1999); Tokhay (2016); Bulut (2012); Direk (2018) ve Toker (2015) çalışmaları ile benzer nitelik göstermektedir. Bu durum yöneticilerin duyarlı, adaletli, demokratik, şeffaf, hoşgörü gibi birçok etik değere sahip olmasının çalışma ortamını olumlu etkilediği ve çalışanları pozitif yönde motive ettiğini göstermektedir.

Araştırmada karizmatik güç, bilgi gücü ve uzmanlık gücünün etik liderliği etkilediği belirlenmiştir. Karizmatik güç, bilgi gücü ve uzmanlık gücü bir araya gelince etik iklimi yordamaktadır. Karizmatik gụ̈,, bilgi gücü, uzmanlık gücü; etik iklimi yordaması Ansari, Aafaqi ve Chiun'un (2015) çalı̧̧ması ile benzerlik göstermektedir. Örgütsel güç içerisindeki karizmatik güç, bilgi gücü ve uzmanlık gücünün yöneticinin etkisini güçlendirirken, ödül gücü, yasal güç ve zorlayıcı gücün ise yöneticiye herhangi bir katkı sağlamadığı görülmektedir. Yöneticinin elinde bulundurduğu karizmatik, uzmanlık ve bilgi gücü astların yöneticilerle iletişimini güçlendirdiği görülmektedir. Bu şekilde astların, daha yüksek tatmin ve performans sergilediği ortaya çıkmaktadır. Tüm bu olumlu güçleri elinde tutan yöneticinin sağladığı barışçıl, huzurlu, adil, yardımsever 
ortamın ve birlikte iş yapabilme becerisinin kurumundaki verimliğe katkısı yadsınamaz derecede önem taşımaktadır. Böyle bir çalışma ortamında etik iklimin oluşması istenilen bir sonuçtur.

Karizmatik güç, bilgi gücü, uzmanlık gücü; etik liderliği yordaması Erdoğan, Liden ve Kramier (2006); Cogliser ve Schriesheim (2000); Erchul, Raven ve Wilson (2004) ve French ve Raven'ın (1959) çalışmaları ile benzerlik göstermektedir. Liderlerin adil davrandığını ve çalışanlarına destekleyici davranışlar sergileyeceklerine ilişkin algıları, lidere olan bağlılıklarını artırmakta ve bu durum lider ile üye arasında yüksek kaliteli bir ilişki ortaya çıkarması da bu araştırmayı destekler niteliktedir. Örgütsel gücün etik liderliği güçlendirdiği, dolayısıyla da etik iklimi sağladığını söylemek mümkün olabilir. Etik liderlik artıkça etik ikliminde pozitif yönde artış gösterdiği, iş verimliliğini ve kalitesinin de $\operatorname{arttığı~söylenebilir.~Çalışan~ve~yönetici~arasındaki~ilişkinin~kalitesi~}$ kurumda görev yapan kişilerin uyumuna ve performansına etki sağlayacaktır; bu da etik iklim algısının olumlu yönde etkileyebilir.

Alan yazına bakıldığında zorlayıcı güç, çıktılarla olumsuz yönde ilişkilidir. Zorlayıcı güç kişinin insanları cezalandırarak ya da tehdit ederek etkileme yeteneğidir (Lunenburg, 2012). Zorlayıcı gücün olumsuz etkileri vardır. Kullanıldığı kişide hayal kırıklığı, korku, intikam, yabancılaşma gibi olumsuz etki bırakmaktadır. Bu da düşük performansa, memnuniyetsizliğe ve tükenmişliğe sebep olmaktadır (Pfeffer, 1993). French ve Raven (1959) 'a göre de zorlayıcı güç itaatsizlik eden insanları cezalandırmak ve yönetmek için kullanılan olumsuz bir güç türüdür.

Zorlayıcı gücün etik iklim ve etik liderlik ile ilişkisinin olmaması bu çalışmayı diğer alan yazında yer alan çalışmalardan ayıran önemli bir özelliktir (Diş ve Ayık, 2016; Nartgün- Sezgin, Nartgün ve Arıcı, 2016). Yöneticilerin zorlayıcı güç kullanmadan sergiledikleri etik davranışlar kurumda çalışanların iş birliği içinde olmalarını, birbirlerine destek vermelerini sağladığı için güvenli bir ortam oluşarak etik iklimin olumlu olmasını sağlayabilir. Etkili liderler zorlayıcı güce bağlı kalmazlar çünkü bu güç, astları ile olumlu bir iklim yaratmalarını önler (Mooney, 2003). Başarılı yöneticiler zorlayıcı gücü kullanmaktan kaçınırlar. Yöneticilerin sahip olduğu etik liderlik tarzının çalışanları zorlayıcı bir etkisinin olmadığını gösterir. Alan yazında zorlayıcı güç ödül gücünün tam tersidir (Hoy \& Miskel, 2005). Bu sebeple etik liderlik ile zorlayıcı güç arasında ilişki olmaması şaşırtıcı olmayabilir.

Zorlayıcı gücün etik iklim ve etik liderlik ile herhangi bir ilişki içinde olmaması da zorlayıcı gücün yöneticiler tarafından olumsuz yönde kullanılmadığını, astların bir yükseköğretim kurumunda çalışma kriterlerinin ya da şartlarının bilincinde olduklarını ve zorlayıcı gücün kendi içlerinde hissetmelerinden kaynaklanmış olabilir. Aslında astların kendi içlerinde reddedilme ve alay edilme korkusunu içlerinde barındıran onların grubun standartlarına uymasını sağlayan kendi zorlayıcı güçleri vardır.

Birçok kurum çalışanının davranışını kontrol etmek için takım üyelerinin zorlayıcı gücünü kullanmaktadır. Üniversitede çalışan akademisyenler kendileri tek başına bireysel olarak çalışmaktadırlar. Akademisyenlerin bilimsel çalışma yapıp yayın 
üretmenin yanı sıra görevde yükselmek için ve özlük haklarının iyileşmesi için üniversitenin belirlediği kriterler doğrultusunda devamlı çalışmaları gerektiğini bilirler. $\mathrm{Bu}$ yapılanlarda üniversitenin kalitesini arttırır. Zorlayıcı güç olumsuz yönde değil akademik personeli olumlu yönde etkiler. Bir yaptırım gücü vardır ama bu yaptırım gücü olumlu sonuçlar ortaya çıkarmaktadır. Zorlayıcı güce ihtiyaç vardır, zorlayıcı gücün varlığını kabul ettikleri için üniversitede çalışmaktadır. 2547 sayılı Yükseköğretim Kanunu'nda (1981) öğretim üyelerinin görevleri; a. Yükseköğretim kurumlarında ve bu kanundaki amaç ve ilkelere uygun biçimde ön lisans, lisans ve lisansüstü düzeylerde eğitim- öğretim ve uygulamalı çalışmalar yapmak ve yaptırmak, proje hazırlıklarını ve seminerleri yönetmek, b. Yükseköğretim kurumlarında, bilimsel araştırmalar ve yayımlar yapmak" olarak birebir işlenmiştir.

Yurtiçinde ve yurt dışında yapılan çalışmalara bakıldığında örgütsel güç, etik iklim ve etik liderlik ile ilgili ayrı ayrı ya da ikili çalışmalara rastlanmaktadır. Örgütsel güç konusunda çalışma sayıca fazla değildir. Özellikle bu araştırma yurt içinde ve dışında bu üç değişkeni aynı anda inceleyen ilk çalışmadır. Tek bir güç kaynağının bulgular arasında ön planda yer almadığı gözlemlenmektedir. Tam tersine ihtiyaçlara göre farklı güç kullanımları göze çarpmaktadır.

\section{Kaynaklar}

Ansari, M.A., Aafaqi, R. \& Chiun, L.M. (2015). Influence tactics and attributed bases of leader power: the role of leader-member exchange. Research advances in organizational behavior and human resources management. (Publication No. 277309449) University Of Paris-Dauphine: https://www.researchgate .net/publication/

Aydan, S. (2017). Sağllk sektöründe etik iklim ve örgütsel güvenin ihbarcllık (whistleblowing) niyeti üzerine etkisi: Bir üniversite hastanesi örneği. (Yayınlanmamış doktora tezi). Hacettepe Üniversitesi, Ulusal Tez Merkezi.

Aydın, İ. (2018). Eğitim ve ögretimde etik. Pegem.

Aydın, M. (2018). Eğitim yönetimi. Gazi.

Balcı, A. (2018). Sosyal bilimlerde araştırma yöntem, teknik ve ilkeler. Pegem.

Bilgen, A. (2014). Çalışanların etik liderlik ve etik iklim algllamalarının örgütsel bağlllıklarına etkisi: özel ve kamu sektöründe karşılaştırmall bir uygulama (Yayınlanmamış Yüksek Lisans Tezi). Bahçeşehir Üniversitesi, Ulusal Tez Merkezi.

Bourdieu, P. (1988). Homo academicus (Trans: P. Collier). Stanford University Press.

Brown, M. E., Trevino, L. K., \& Harrison. D. A. (2005). Ethical leadership: a Social learning perspective for construct development and testing. Organizational Behavior and Human Decision Processes, 97(2), 117-134. 
Bulut, H. (2012). Etik liderliğin ve etik iklimin çalışanların örgütsel bağlılı̆̆ına ve iş performanslarına etkileri (Yayınlanmamış yüksek lisans tezi). Gebze Yüksek Teknoloji Enstitüsü, Ulusal Tez Merkezi.

Bursalığlu, Z. (2016). Eğitim yönetiminde teori ve uygulama. Pegem.

Bustos-Vargas, D. E. (2016). Exploring the relatıonship between leadership sources of power and authentic leadership style in speech-language pathology. (Publication No. 10405500). Lake University, ProQuest Dissertations and Theses Global.

Büyüköztürk, Ş. (2014). Sosyal bilimler için veri analizi el kitabl. Pegem.

Büyüköztürk, Ş., Çakmak-Kılıç E., Akgün M. E., Karadeniz, Ş. \& Demirel, F. (2018). Eğitimde bilimsel araştırma yöntemleri. Pegem.

Cevizci, A. (2017). Felsefe tarihi. İstanbul: Say.

Cogliser, C.C. \& Schriesheim, C.A. (2000). Exploring work unit context and leadermember exchange: a multi-level perspective. Journal of Organizational Behavior. 21(5), 487-511.

Cömert, M. (2014). Öğretmenlerin örgütsel bağlllık düzeyleri ile okul müdürlerinin kullandıklarl örgütsel güç kaynakları arasındaki ilişkinin incelenmesi (Yayımlanmamış Yüksek Lisans Tezi). Kahramanmaraş Sütçü İmam Üniversitesi, Ulusal Tez Merkezi.

Cullen, J., Victor, B., \& Bronson, J. W. (1993). The ethical climate questionnaire: An assesment of its development and validity. Pschological Reports, 73(2), 667-674

Decker, S. R. (1989). The relationship among principal power tactic usage, leadership style and school climate in selected Iowa elementary schools (Publication No. 222998322) (Unpublished Doctoral Dissertation), University of Northern Iowa, Iowa. https://core.ac.uk/download/pdf/222998322.pdf

Direk, H. (2018). Etik liderlik davranışının etik iklim ve örgütsel güvene etkisi (Yayınlanmamış yükssek lisans tezi). Kırıkkale Üniversitesi

Diş, O. \& Ayık, A. (2016). Okul yöneticilerinin kullandıkları güç kaynakları ile örgüt iklimi arasındaki ilişki. Akademik Bakış Dergisi, 58, 499-518.

Erchul, W. P., Raven, B.H. \& Wilson, K.E. (2004). The relationship between gender of consultant and social power perceptions within school consultation.School Psychology Review, 33(4), 582-590. https://doi.org/10.1080/02796015. 2004.12086269

Erdoğan, B., Liden, R.C. \& Kramier, M.L. (2006). Justice and leader-member exchange: the moderating role of organizational culture. Academy of Management Journal, 49(2), 395-406. https://doi.org/10.5465/amj.2006.20786086 
Eyidoğan, Ö. (2013). Etik iklimin örgütsel iletişsim üzerindeki etkisi (Yayınlanmamış Yüksek Lisans Tezi). Marmara Üniversitesi, Ulusal Tez Merkezi.

French, J. R. P., \& Raven, B. (1959). The bases of social power. In D. Cartwright \& A. Zander (Eds.), Studies in social power (s. 150-167). MI: University of Michigan.

Gündüz, Y. (2015). Etkileşimsel ve dönüsümsel liderlik tarzlarının izleyicilerinin örgütsel güç algisl üzerindeki etkisini incelemeye yönelik bir araştırma (Yayınlanmamış Yüksek Lisans Tezi). Marmara Üniversitesi, Ulusal Tez Merkezi.

Hinkin, T.R., \& Schriesheim, C.A. (1989). Development and application of new scales to measure. Journal of Applied Psychology, 74(4), 561-567.

Hoy, W. K., \& Miskel, C. G. (2005). Educational administration: Theory, research, and practice (7th ed.). McGraw-Hill.

Jose, A., \& Thibodeaux, M. S. (1999). Institutionalization of ethics: the perspective of managers. Journal Of Business Ethics, 22(2), 133-143.

Kuyucu-Güzel, E. (2019). Akademisyenlerin eleştirel düşünme düzeyleri ile örgütün etik iklimine ilişskin algıları arasındaki ilişkinin incelenmesi (Yayınlanmamış yüksek lisans tezi). Celal Bayar Üniversitesi, Ulusal Tez Merkezi.

Lunenburg, F. C., \& Ornstein, A. C. (2013). Liderlik. F. C. Lunenberg, A. C. Ornstein. (D. Doğan, Çev.), Ĕgitim yönetimi. G. Arastaman (Çev. Ed.). Nobel.

Maya, İ. (2013). Akademisyenlerin meslek ahlakına aykırı olan davranışlara ilişkin ÇOMÜ Eğitim Fakültesi Örneği. International Periodical For The Languages, Literature and History of Turkish or Turkic. 8(6), 491-509.

Mendonca, M. (2001). Preparing for ethical leadership in organizations. Canadian Journal of Administrative Sciences, 18(4), 266-276.

Meydan, C. H. (2010). Örgüt kültürü, örgütsel gü̧ ve örgütsel adalet algllarının bireyin iş tatmini ve örgüte bağlllı̆̆ üzerine etkisi: Kamuda bir araştırma Yayınlanmamış Doktora Tezi). Kara Harp Okulu, Ulusal Tez Merkezi.

Mintzberg, H. (1983). Power in and around organizations. Englewood Cliffs NJ: Prentice Hall.

Mintzberg, H. (1985). The organization as political arena. Journal of Management Studies, 22(2), 133-154.

Mooney, M. (2003). A study of the relationship between transformational leadership and organizational climate of elementary schools in western Pennsylvania.

(Publication No. 3081035) (PhD Dissertation). Duquesne University. ProQuest Dissertations and Theses Global.

Murray, V. \& Gandz, J. (1980). Games executives play: politics at work. Business Horizons, 23(6), 11-23. 
Nartgün- Sezgin, Ş., Nartgün, Z. \& Arıcı, D. (2016). Okul yöneticilerinin kullandıkları örgütsel güç kaynakları ile otantik liderlik düzeylerine ilişkin öğretmen görüşleri. Çă̆daş Yönetim Bilimleri Dergisi, 2(2), 1-26.

Nietzsche, F. (2017). Güç istenci (N. Epçeli, Çev.). Say.

Özcenay, T. (2017). Okul yöneticilerinin kullandıkları güç kaynaklarına ilişkin yönetici ve ögretmen görüşlerinin değerlendirilmesi (Yayınlanmamış Yüksek Lisans Tezi). Yakın Doğu Üniversitesi, Ulusal Tez Merkezi.

Özdemir, A. (2015). Öğretmenlerin okullarına duygusal bağlılıklarının müdürlerin sosyal, kullandıkları güç kaynakları ve etik liderlik davranışları açısından incelenmesi. Gazi Üniversitesi Gazi Eğitim Fakültesi Dergisi, 35(3), 595-618.

Özdemir, E. (2003). Liderlik ve etik. Uludağ Üniversitesi İktisadi ve İdari Bilimler Fakültesi Dergisi, 12(2), 151-168.

Özen, F. \& Durkan, E. (2016). Algılanan örgütsel etik iklim ile öğretmenlik meslek etiğgi arasındaki ilişki. Kuram ve Uygulamada Eğitim Yönetimi, 22(4), 593-627. https://doi.org/10.14527/kuey.2016.023

Peterson, D. K. (2002). The relationship between unethical behavior and the dimensions of the ethical climate questionnaire. Journal of business ethics, 41(4), 313-326.

Pfeffer, J. (1993). Managing with power. Harward Business School.

Platon. (2010). Devlet. Türkiye İş Bankası.

Polat, S. (2010). Okul öncesi yöneticilerin kullandıkları yönetsel güç kaynaklarına ilişkin ögretmen algllarl ile ögretmen motivasyonu arasındaki ilişki (Yayınlanmamış Yüksek Lisans Tezi). Yeditepe Üniversitesi, Ulusal Tez Merkezi.

Raven, B. H., Schwarzwald, J., \& Koslowsky M. (1998). Conceptualizing and measuring a power interaction model of interpersonal influence. Journal of Applied Social Psychology, 28(4), 307-332.

Russel, B. (1990). İktidar (M. Ergin, Çev.). İzmir: Cem Yayınevi.

Scott, J. C. (1995). Tahakküm ve direnişs sanatları (A. Türker, Çev.). Ayrıntı yayınları.

Toker, M. E. (2015). Tepe yöneticinin otantik ve etik liderlik davranışlarının etik iklim algısına etkisi ve bir araştırma (Yayınlanmamış yüksek lisans tezi). Toros Üniversitesi.

Tokhay, E. (2016). Etik iklim ile etik liderlik arasındaki ilişki ve bir araştırma (Yayınlanmamış yüksek lisans tezi). Bahçeşehir Üniversitesi, Ulusal Tez Merkezi.

Tuna, M., Bircan, H. ve Yeşiltaş, M. (2012). Etik liderlik ölçeğinin geçerlilik ve güvenilirlik çalışması: Antalya örneği. Atatürk Üniversitesi İktisadi ve İdari Bilimler Dergisi, 26(2), 142-155. 
Victor B. I., \& Cullen J. B. (1988). The organizational bases of ethical work climates. Administrative Science Quarterly, 33(1), 101-125.

Yılmaz, K. \& Altınkurt, Y. (2012). Okul yöneticilerinin kullandıkları güç kaynakları ile öğretmenlerin iş doyumu arasındaki ilişki. Kastamonu Eğitim Dergisi, 20(2), 385402.

Yükseköğretim Kanunu (1981) https://www.mevzuat.gov.tr/MevzuatMetin 11.5.2547.pdf. 